\title{
A Nozickian Case for Compulsory Employment Injury Insurance: The Example of Sweatshops
}

\author{
Damian Bäumlisberger ${ }^{1,2}$ D
}

Received: 7 April 2019 / Accepted: 12 May 2020 / Published online: 9 June 2020

(c) The Author(s) 2020

\begin{abstract}
Production in sweatshops entails an elevated risk of occupational injury and sickness due to accidents and exposure to dangerous working conditions. As most sweatshop locations lack basic social security systems, health problems have severe consequences for affected workers. Against this background, this article considers what obligations employers of sweatshop labor have to their workers, and how they should meet them. Based on core libertarian concepts, it shows that they are morally responsible for health problems caused by their management decisions, that they should compensate affected workers, and that they must prevent potentially irreversible health problems. In line with Nozick's contractarian method, the article further argues that these obligations should be implemented through a compulsory employment injury insurance system. Such a system would impose industry-wide health and safety standards, in contrast to the view that libertarianism excludes any labor regulation for the protection of workers, as an illegitimate interference in voluntary labor contracts.
\end{abstract}

Keywords Employment injury insurance $\cdot$ Incomplete contracts $\cdot$ Labor regulation $\cdot$ Libertarianism $\cdot$ Robert Nozick · Sweatshops · Worker's compensation insurance

\section{Introduction}

Sweatshops are production sites, where low-skilled workers produce textiles and clothing, toys, simple household appliances, and other labor-intensive consumer goods in hazardous working environments and for subsistence wages (Miklós 2017). Sweatshop labor regularly involves an elevated risk of occupational injury and illness, due to work accidents and the exposure of workers to unhealthy working conditions. Because many locations of sweatshop production lack basic social security systems, occupational health problems generally have dire consequences for affected workers. In addition to losing their jobs, many of them are deprived of their ability to make a living for themselves and their families in the future.

This precarious situation of sweatshop workers raises the normative issue of how sweatshop owners should treat

Damian Bäumlisberger

damian.baeumlisberger@googlemail.com

Esslingen am Neckar, Germany

2 Institute of Economic Education, University of Münster, Münster, Germany them (Maitland 1997), more precisely, to what extent they should be held responsible for occupational health hazards, and what obligations they have towards workers who (could) suffer harm through their work activities. This translates into the broader question of whether sweatshop owners, regulators, purchasers of sweatshop goods or end consumers should actively promote institutional conditions for the implementation of potential obligations.

The business ethics literature on these issues is controversial. Proponents argue that sweatshop labor is exploitative, coercive and/or harmful (Coakley and Kates 2013), and should be regulated in terms of health and safety standards, maximum working hours, and minimum wages (Arnold and Bowie 2003, 2007; Carson 2013; Preiss 2014; Kates 2015; Miklós 2017). Critics counter that sweatshop labor is a Pareto-optimal improvement over even worse types of labor. They reject regulation as worsening the situation of workers by inflating wages beyond equilibrium levels, thus producing involuntary unemployment and general welfare losses (Greene et al. 2007; Powell 2018; Powell and Zwolinski 2012; Sollars and Englander 2007, 2018).

This article offers a new perspective to the debate, approaching the issues of employer responsibility for occupational health hazards, and their respective obligations 
towards workers, from a libertarian perspective. Based on the core libertarian concepts of (self-)ownership, contractual entitlement, and non-interference, it argues that employers are responsible for health problems attributable to worker compliance with management decisions, that they should compensate affected workers only to the extent of their contractual entitlement before the health problem, but that they must introduce health and safety standards to prevent irreversible health problems that permanently interfere with the ability of workers to pursue self-chosen ends in life.

Based on Nozick's contractarian method (1974), this article then argues that these obligations should be implemented by means of a compulsory employment injury insurance system. This system should impose rules for financing and distributing compensation in the event of health problems, and it should introduce industry-wide health and safety standards. Because it would exhibit core characteristics of a state institution, the second part of the argument is a libertarian case for sweatshop regulation. As such it poses a challenge to critics of such regulation, especially to proponents of the choice argument against it (e.g., Zwolinski 2007). It offers a counterexample to their general claim that any regulation interferes with voluntary labor contracts (e.g., Flanigan 2018), thus inviting them to adjust the scope of their claim or to refine their normative premises.

The contribution of the article to the literature is that it introduces a relevant and new perspective to the controversial debate on sweatshop regulation. This perspective transcends existing conflict lines and should inspire and stimulate new approaches to various normative issues in relation to sweatshop labor. Furthermore, the article makes two original contributions to theory development. First, it develops the implications of key libertarian concepts for occupational health risks within incomplete labor contracts. Second, it applies a refined version of Nozick's (1974) contractarian approach to the domain of business ethics and uses it to justify the core labor market institution of compulsory employment injury insurance.

Section "Health Risks in Sweatshops and Worker's Compensation" describes the nature of sweatshop labor, related health risks and existing institutions for dealing with them. Section "Libertarianism" introduces key libertarian concepts, which Section "Libertarian Responsibility and Obligations in Incomplete Labor Contracts" then develops into an account of the obligations of employers towards their workers. Section "From Libertarian Obligations to Compulsory Insurance: A Nozickian Case" provides the Nozickian case for compulsory employment injury insurance, and Section "Conclusion" rounds off the article.

\section{Health Risks in Sweatshops and Worker's Compensation}

Sweatshop labor is a form of employment that involves strenuous manual work, long working hours, hazardous working conditions and comparatively low wages. Employers use it in the production of labor-intensive intermediate products for cars, household appliances or consumer electronics goods (Kates 2015), and in the production of consumer goods such as clothes, shoes, kitchenware or toys (Lin-Hi and Blumberg 2017). Most sweatshops form part of industrial clusters in developing countries with an abundant supply of low-skilled workers (Zeng 2010, 2012; Barrientos et al. 2011; Gereffi and Lee 2016).

Sweatshop production is associated with a particularly high risk of occupational illness and injury, which can lead to work incapacity, permanent disablement or even premature death. Occupational illness may result from obvious causes like the exposure to hazardous materials or toxic fumes, as in some leather tanning, electronics and mining industries (e.g., Wang et al. 2011). Moreover, it can be a long-term effect of less obvious unhealthy working conditions in the form of long workdays without regular breaks, a stressful working environment, systematic abuse by superiors, as in some textile and footwear industries (e.g., Malik et al. 2010). Occupational injuries occur in the process and context of operating sharp tools, heavy devices, automated machines, and other types of industrial equipment, and they often result in chronic health problems.

Despite the very limited (reliable) data on occupational accidents and diseases in developing countries (ILO 2012, p. 28), several empirical studies do indeed show that workers face an appreciably higher risk of work-related sickness, injury and death in comparison to those in developed countries (e.g., Hämäläinen et al. 2009; Wu et al. 2018). A recent global estimate by the World Safety and Health Institute Singapore, in cooperation with the International Labor Organization (ILO), and based on classifications of the World Health Organization, reveals a much higher occupational fatality rate in less developed world regions like Asia and Africa, at 12.99 and 17.39 deaths per 100,000 people, respectively, than in more developed regions like Europe at 3.61 work-related deaths per 100,000 (Hämäläinen et al. 2017). A range of country- and industry-specific studies corroborates this general picture. ${ }^{1} \mathrm{In}$ 2013, an unusually severe industrial accident attracted particularly close media attention (e.g., Guardian 2018; NYT

\footnotetext{
${ }^{1}$ Wang et al. (2011) provide evidence to support the considerable occupational health and safety challenges in Chinese township- and village-owned enterprises; Malik et al. (2010) for those in the Pakistani textile industry, and Velazquéz et al. (2008) for those in the Mexican automotive refinishing industry.
} 
Table 1 Typology of contributions to the sweatshop debate. Source Own presentation

\begin{tabular}{|c|c|c|}
\cline { 2 - 3 } \multicolumn{1}{c|}{} & Narrow Institutional Analysis & Broad Institutional Analysis \\
\hline $\begin{array}{c}\text { Specific } \\
\text { Normative } \\
\text { Grounding }\end{array}$ & $\begin{array}{c}\text { Specific normative approach with } \\
\text { specific implications (this article) }\end{array}$ & $\begin{array}{c}\text { Specific normative approach } \\
\text { with broad implications only }\end{array}$ \\
\hline $\begin{array}{c}\text { Pluralistic } \\
\text { Normative } \\
\text { Grounding }\end{array}$ & $\begin{array}{c}\text { General normative approach with } \\
\text { specific implications }\end{array}$ & $\begin{array}{c}\text { General normative approach } \\
\text { with broad implications only }\end{array}$ \\
\hline
\end{tabular}

2018). The collapse of the Rana Plaza textile factory building in Bangladesh with 1134 dead and around 2500 injured workers (ILO 2018), has since then developed into a focal point for political (ABWZ 2014; BMZ 2016; PST 2019) and scientific discourse (Alamgir and Alakavuklar 2018; Fontana and EgelsZandén 2018) on working conditions in sweatshops.

In response to similar problems in the early stages of industrialization, most developed countries have established some form of employment injury insurance system (Shin et al. 2011). Historically, these systems emerged from mutual insurance programs, managed by trade unions or miners' associations as in Germany (Jopp 2010, 2013) or from precedent cases in legal disputes over employer liability as in the US (Epstein 1982). In cases of an occupational illness or injury, they provide affected workers with replacement income and medical care. These in-cash and in-kind benefits aim at securing the livelihood of incapacitated workers and restoring their health and earning capacity as well as possible. In cases of permanent disability or death, they provide lifelong benefits to affected workers or surviving dependents (Larson 1952; ILO 2017).

The right to protection against occupational injury is widely recognized internationally. As an integral part of core UN values, it is enshrined in the Declaration of Human Rights and the International Covenant on Economic, Social and Cultural Rights (ILO 2017). Moreover, widely ratified ILO conventions, like part VI of the Social Security (Minimum Standards) Convention No. 102 and the Employment Injury Benefits Convention No. 121 aim at globally promoting accident and disease prevention, as well as the recovery and compensation of affected workers (ibid)

In the business ethics literature there is fundamental disagreement on the normative questions of how to assess the ethical problems of sweatshop labor and of how to deal with them institutionally. In the literature, normative assessment is either developed from a specific ethical theory or is based on a pluralistic grounding that does not commit to a particular normative principle. Moreover, the associated analysis of possible institutions for realizing normative claims either focuses on specific types of sweatshop regulation, or is based on a broad assessment of sweatshop regulations in general (see Table 1).
Arnold and Bowie (2003, 2007), for instance, develop their criticism of working conditions in sweatshops from a specific Kantian angle, and advocate a wide range of institutional practices to improve them. Similarly, Coakley and Kates (2013) base their general critique of possible institutional responses to problematic labor practices on a specific normative standard of worker welfare.

Sollars and Englander (2007) analyze minimum wages, as a particular institution, based on a broad theoretical framework that draws on various economic and ethical concepts. Likewise, Miklós (2017) addresses the specific phenomenon of institutional exploitation, based on a broadly defined normative framework that can accommodate several standards of justice.

Finally, proponents of the choice argument (e.g., Zwolinski 2007; Flanigan 2018) and their critics (e.g., Kates 2015) develop their analysis of a large variety of institutional responses to ethical problems in sweatshops on pluralistic normative grounds (Zwolinski 2007, p. 690; Powell and Zwolinski 2012, p. 450; Kates 2015, p. 192; Flanigan 2018, p. 81), which means that they "frame [...] it in a way that it remains valid given a wide range of conflicting assumptions about foundational moral questions" (Zwolinski 2007, p. 690).

This present article breaks fresh ground by developing an argument for the specific labor market institution of compulsory employment injury insurance, based on the specific normative perspective of (Nozickian) libertarianism. Section "Libertarianism" outlines relevant libertarian concepts used in the subsequent analysis.

\section{Libertarianism}

Libertarianism is a morally grounded approach to political philosophy which includes a set of views on individual rights and duties, distributive justice and political organization. It strictly prioritizes individual freedom over other values, and tends to reject moral duties towards others beyond a negative duty of non-interference (Christmas 2018) or non-aggression 
(Rothbard 1998). It objects to coercive redistribution between individuals, and sets strict limits to state activity.

Libertarianism builds on the normative claim that individuals have (natural) rights, which others should not violate without prior consent (e.g., Nozick 1974, p. ix). On most accounts, individuals possess them "by virtue of their status as human beings" (Zwolinski 2008, p. 3), more precisely because of their status as self-owners. Self-ownership captures the "view that agents initially fully own themselves" and should have "the kind of control over themselves that one might have over possessions" (van der Vossen and Vallentyne 2018, ch. 1). This includes the right to use their bodies and minds as they wish and to allow or deny such use to others.

Self-ownership furnishes individuals with the ability "to acquire property rights in external things" (ibid). Different strands of libertarianism disagree on the mechanism of how self-owners can acquire possession of previously unowned things. However, most attach great importance to the observation of property rights, once the initial acquisition has taken place (Zwolinski 2016). On most accounts, individuals may freely dispose of their person and things. They are free to transfer their ownership rights to others and may cooperate with them based on voluntary contracts (Nozick 1974, p. 150). For libertarians, subjective preferences and values are the core standard for judging people's choices. Based on the notion that everyone knows best what is most important to him or her (Buchanan 1990), they will not rank these choices according to a normative standard of objective importance (an economic discussion in Müller and Tietzel 2001). Moreover, most of them would hold that parties to a voluntary contract are entitled to the contractual service promised to them (Nozick 1974, p. 151) or to the property title transferred to them (Rothbard 1998, ch. 19) by their contracting partners.

In a world of scarce space, time and resources, self- and property-owning individuals will inevitably get in each other's way. Therefore, a key concern of libertarians is the identification of a suitable normative criterion for balancing out individual freedom. Most of them grant people the right to use their freedom at will, as long as this does not interfere with the self-chosen ends of others without their prior consent (Christmas 2018). Many of them identify interference with aggression (Child 1994, p. 728), for example in the form of physical violence, coercive threats, or robbery. However, only some libertarians view the protection from coercive interference as absolute (Zwolinski 2016). Many allow small and trivial unauthorized interferences, such as in the form of a few dust particles that settle on an unsuspecting individual, or if interferences protect a more basic right, e.g., when an unauthorized push saves a person from being hit by a vehicle (van der Vossen and Vallentyne 2018, ch. 1).
Strictly speaking, libertarianism only prohibits the initiation of aggression (Zwolinski 2016, p. 64). The "firstorder rights" to self-ownership and property entail the "second-order rights [...] to defend against forceful attack and coercion by force or threats of force" and "to defend one's legitimately acquired property against seizures by force or threats of force" (Child 1994, p. 728). After an unauthorized violation of their first-order rights, individuals may claim compensation from an aggressor (van der Vossen and Vallentyne 2018, ch. 1). By the 'principle of rectification' (Nozick 1974, p. 152), they may seek redress for the suffered damage in accordance with the principle of proportionality. Under conditions of anarchy they may, for instance, seize a stolen object or confiscate a suitable compensation payment from rights violators. By some accounts, libertarianism condones the prohibition of actions that pose a serious health risk to a person or her rightful property. For instance, residents would be entitled to keep the owner of a chemical plant from poisoning their land to protect their health.

Finally, self-owners may delegate their rights to others. They may instruct them to conclude contracts for them, to enforce their contractual claims, to protect them from coercion, to demand compensation or to exercise prior restraint for them. While some libertarians reject all state activity (e.g., Rothbard 1998), most of them will accept it, if officials act under the authority of self-owning individuals and in the exercise of their legitimate rights (e.g., Vallentyne 2007). With very few exceptions libertarians require the delegation of the second-order rights to self-defense to an impartial, minimal state (e.g., Nozick 1974). Libertarians tend to be skeptical towards state interference beyond this level. They are particularly critical of regulation that interferes in voluntary contracts, because this coercively overrides the expressed will of contractors. The following section applies the outlined libertarian concepts of self-ownership, contractual entitlement and non-interference to the issue of occupational health problems in sweatshops. In view of the research question, it enquires what moral responsibilities, and what employer obligations they might entail in the event of occupational accidents and illnesses.

\section{Libertarian Responsibility and Obligations in Incomplete Labor Contracts}

A libertarian analysis of employer obligations for occupational health problems must take into account the characteristics of sweatshop labor, and consider the fact that the mutual agreement to enter an employment relationship is a very special market transaction which is

(i) temporally unlimited, as it typically holds until unilaterally terminated 
(ii) unspecific on the nature of the service, as workers make their labor freely available

(iii) adaptive, as specific work requirements must be adapted to changing circumstances

(iv) hierarchical, as workers agree to follow employer instructions to the best of their ability

By virtue of these characteristics, labor contracts are systematically incomplete (Barnett 1992b, p. 821). They are temporally unlimited in order to save both parties the transaction costs of having to negotiate detailed short-term contracts for each task or day (Coase 1937). They are unspecific on the exact nature of contractual services (Tirole 1999), as it would be prohibitively costly, or indeed literally impossible, to anticipate "the precise actions that each party to the contract should take in every conceivable eventuality" (Hart and Moore 1985, p. 1). They are adaptive, because production and working conditions are in constant need of realignment with changing market requirements. Finally, they give employers hierarchical control over the organization of work in their factories, in order to protect their financial interests from recurring renegotiation attempts of workers in light of changing circumstances (Williamson 2002).

Through a typical labor contract, workers receive a fixed and regular wage for an indefinite period in exchange for making their labor freely available. Employers may determine if and how the available labor is put to use in their production sites and on their machines, in return for bearing the entrepreneurial risk in terms of possible profits or financial losses after deducing all costs. This profit claim also serves as a "title to the net earnings of the team" which motivates employers to ensure the efficiency of the overall team effort (Alchian and Demsetz 1972, p. 782).

These features of a typical work relationship make it clear why a libertarian analysis of responsibilities and obligations in the event of accidents is important, despite the libertarian right of workers and employers to specify any mutually acceptable provisions in their labor contract. The outcome of such an analysis can be seen as a libertarian set of default rules that fills inevitable gaps in incomplete labor contracts, either in the sense of non-negotiable "baseline background conditions" that prohibit unacceptable practices like coercion and fraud (Sturn 2009, p. 81); in the sense of "rules that parties can contract around by prior agreement" and that serve the purposes of making them reveal their preferences on important issues (Ayres and Gertner 1989, p. 87) or in the sense of one of several possible focal points in contract negotiations that facilitate the coordination of contractors on mutually acceptable contract clauses (Schelling 1980; McAdams 2000, 2015). The next section analyzes the moral responsibility for occupational accidents, based on the libertarian concept of self-ownership.

\section{Moral Responsibility for Occupational Health Hazards}

Suppose worker W suffers an accident in the factory of employer E. Like most health hazards in sweatshop production the accident is the overall result of their cooperative interaction, and the outcome of W's self-chosen approach to following E's instruction to work on E's machine. What liability rule for such cases should serve as a libertarian default?

From a libertarian perspective, it seems clear that the moral responsibility for the accident should be grounded in W's and E's respective capacities for autonomous action. $\mathrm{W}$ and $\mathrm{E}$ should be held responsible for occupational health issues that arise from the exercise of their control over their persons and the involved physical objects (Talbert 2019, intr.). In the stated scenario, moral responsibility for the accident should be allocated according to the specific actions of $\mathrm{W}$ and $\mathrm{E}$ in the production process that caused them. Accordingly, $\mathrm{E}$ would be responsible for the degree to which W's accident resulted from E's instructions, and E would be responsible for the extent to which it was caused by W's approach to implementing these instructions.

In view of this, it becomes clear that employers have a special and specific form of responsibility for possible health problems in their factories. In a typical labor contract they claim hierarchical control over the work relationship. This contractual claim entails the tasks of managing the production process, of setting up the machines and workplaces, and of allocating assignments to workers. Workers merely agree to make their labor available to employers and to follow employer instructions to the best of their ability. In other words, workers hire out their capacity for autonomous action to employers. Employers may use it for the purpose of producing marketable goods, but - as in any rental arrangement- they are required to take care of the rented 'resource' and to return it 'undamaged' when the contractual relationship is terminated. Hence, the consent of employers to the contract clause that puts them in charge of management decisions and puts the labor of workers at their disposal, makes them, on their own accord, primarily responsible for health problems resulting from worker actions performed at their direction or based on their rules.

If workers were mere objects (or rented out their property to employers) this would make employers fully responsible for possible 'damages' to workers' working capacity that result from their use of their labor (or property). However, the nature of self-ownership makes it impossible for a worker "to alienate his will, more particularly his control over his mind and body" (Rothbard 1998, p. 135; emphasis in the original). Even in the most strictly supervised production process a worker would "retain control over at least some minimal dimension of personal behaviour" (Buchanan 
1995). Therefore, accidents cannot normally be the objects of employer instructions alone, but, at least to a minimal degree, "emerge from the interdependent choices" (ibid) of employers and workers in the production process. This gives workers a co-responsibility for accidents to the extent that their autonomous decisions in the production process, in particular their negligence in implementing employer instructions, contributed to their occurrence.

This complicates the allocation of responsibility for occupational health problems. If W's incapacitating accident is the outcome of gross negligence on the part of W's co-worker $\mathrm{C}$, this raises the question of whether $\mathrm{C}$ should be mainly responsible for W's injuries (as E might argue) (a critical discussion of this line of argument in Epstein 1982). From the outlined libertarian approach this might be the case, especially if C's negligence resulted from his autonomous decisions alone, e.g., from the fact that $\mathrm{W}$ was drunk or deliberately ignoring E's instructions.

However, from a libertarian perspective, E cannot disclaim any responsibility for the negative effects of the negligence or insubordination of some workers on their co-workers. Prima facie E is, of course, entirely free to accept C's violation of the clause in their labor contract that requires diligent compliance with E's instructions. However, this only applies as long as E's and C's approach to fulfilling their contract does not produce any negative external effects on third parties like W. If a reprimand to $\mathrm{C}$ by $\mathrm{E}$ or E's dismissal of $\mathrm{C}$ in cases of persistent negligence, would have prevented the accident, it is reasonable to attribute a major share of the responsibility for W's health problems to E. This is to say that the hierarchical control of employers entails a co-responsibility for occupational health problems that are attributable to the continued negligence of co-workers.

This leads to the final issue of who should be held responsible for accidents that are simply the result of bad luck beyond the direct control of $\mathrm{W}, \mathrm{E}$, and $\mathrm{C}$ (Lippert-Rasmusen 2018). Some might argue that the resulting damage to W's health and E's machine should be seen as an example of bad option luck, and hence as the unfortunate outcome of a calculated gamble (Dworkin 2000, p. 73), which both of them accepted deliberately at the point of engaging in this risky form of cooperation. By this logic, W should have known that sweatshop labor is a dangerous line of work, and that the attractive income opportunity in comparison to other jobs would come at the price of an isolated risk of unfortunate work accidents that are no one's fault. Accordingly, W would be responsible for coincidental damage to his health, because $\mathrm{W}$ chose to work in a dangerous factory, just as E accepted the risk of coincidental damage to his machines by opening the sweatshop (similarly Flanigan 2018, p. 80 et seq.).

A libertarian perspective on the nature of the firm suggests otherwise. It would hold that the unfortunate accident should be considered as an integral part of the residual risk of the enterprise, and that $E$ accepted this risk in exchange for his exclusive claim to the residual income of the firm. Given that by this arrangement, windfall profits would accrue to E, even if they are not attributable to E's management decisions ${ }^{2}$, E should also be fully responsible for accidents that are the outcome of bad luck and no one's fault. This relation between residual risk, and the claims to hierarchical control and profits is consistent with the shareholder perspective on the firm (an account in Boatright 2006, pp. 113-114), which many consider as inherently libertarian. The next section addresses the implications of the discussed employer responsibility for occupational illnesses and injuries.

\section{An Employer Obligation to Compensate Sick and Injured Workers}

Suppose W suffers an accident that is clearly attributable to a mistake by $\mathrm{E}$. W and $\mathrm{E}$ have specified a contractual rule that makes E fully responsible for the accident, but they forgot to include a clause specifying what actions E's responsibility requires. What should a libertarian default setting specify?

It seems reasonable to assume that it would determine that $\mathrm{E}$ has to provide $\mathrm{W}$ with an equivalent to what $\mathrm{W}$ lost due to the accident. Accordingly, it would assess the damage to $\mathrm{W}$ against the counterfactual scenario of what $\mathrm{W}$ would have been entitled to by their contract, if the accident had not occurred (Nozick 1974, p. xx). Given that the accident resulted from a financially motivated cooperative effort, it is likely that a libertarian default rule would foresee a financial equivalent to the victim's losses. Because their cooperation consisted of combining their resources of capital and labor, it would probably require the originator to restore the damaged resource of the victim. In the above scenario, E would have to bear all the medical expenses that $\mathrm{W}$ must incur to fully recover his working capacity, so that $\mathrm{W}$ can again offer the same quality and amount of labor to $E$ or on the market. Moreover, E would have to provide $\mathrm{W}$ with a compensation payment equal to the income loss until $\mathrm{W}$ has fully recovered. Analogously, if W caused damage to one of E's machines, $\mathrm{W}$ would have to compensate $\mathrm{E}$ to the value of the repair costs and the projected production losses.

Such a monetary approach to compensation is salient, because it enables the application of a general rule to all possible accident and damage scenarios that might arise in complex and unpredictable work relationships. However, from a libertarian perspective, a strictly monetary compensation can lead to an undesirable commodification of natural rights. It can give rise to a scenario in which employers deliberately accept serious risks to the health of workers based on a strict

\footnotetext{
2 They might be due to sudden market price increases for the produced goods in the wake of a natural disaster.
} 
cost-benefit analysis. In even worse cases, it might permit the deliberate purchase of rights violations. The next section discusses the obligation of employers for the prevention of occupational health problems.

\section{An Employer Obligation to Protect the Health and Safety of Workers}

Suppose E causes $\mathrm{W}$ a health problem that leaves him permanently disabled and unfit to work, despite all efforts to restore his health. As specified in the labor contract, E takes full responsibility for the causative management error, and in addition to all the medical costs, pays $\mathrm{W}$ a lifelong invalidity pension to the value of W's former income. In a libertarian default setting, should this count as a restoration of the state before the accident?

A libertarian perspective rejects this view, based on the consideration that the accident permanently deprived $\mathrm{W}$ of essential parts of his capacity as an autonomous self-owner. In particular, it holds that the accident seriously diminished W's ability to pursue self-chosen ends in life and hence constitutes a particularly serious form of interference well beyond the contractual relationship with E (Christmas 2018, p. 310). If $\mathrm{W}$ has not explicitly released $\mathrm{E}$ from his negative libertarian duty not to compromise W's ability to pursue self-chosen ends in life (which a minimally prudent $\mathrm{W}$ would not do), W may legitimately expect not to have his life and health jeopardized by E's negligent approach to exercising his managerial control in the production process. It would further posit that, in view of the high stakes for W, E should have exercised his voluntarily accepted managerial control in a particularly prudent manner, and by failing to do so, committed a serious breach of his negative libertarian duty to prevent occupational injuries and illnesses to W. This implies that employers should use their contractual authority to equip machines and organize production in a manner that minimizes serious risks to the health of workers and that protects their capacity to pursue self-chosen ends. This includes an obligation to minimize such risks on the part of co-workers. The next section argues that the specified employer obligations to protect the health of workers and to compensate them in cases of occupational injury and sickness should be implemented according to a compulsory employment injury insurance system.

\section{From Libertarian Obligations to Compulsory Insurance: A Nozickian Case}

The following argument builds on social contract theory and holds that individuals would choose such a system in a counterfactual state of nature, based on certain assumptions about their subjective motives and objective decision situation (Mueller 2002). By virtue of adopting Nozick's contractarian method (1974), the argument has two specific characteristics. First, it proceeds from the most peaceful and comfortable state of nature conceivable (Kliemt 1980, p. 38). This state is populated by voluntarily cooperating sweatshop owners and workers that respect each other's libertarian rights and obligations, as stated in "Libertarianism" and "Libertarian Responsibility and Obligations in Incomplete Labor Contracts" sections, and make their rational decisions in non-desperate circumstances. Against this backdrop, the argument shows that even these most pleasant and respectful anarchists would eventually have to establish a governmental insurance system to resolve their escalating conflicts in the wake of work accidents. Thus, it provides a particularly compelling case for compulsory insurance. In accordance with the second characteristic of Nozickian contractarianism, the argument makes specific assumptions about the individual behavior that produces the contractual outcome (Müller 2002). More specifically, it construes the final agreement on the coercive insurance system as the culmination of a gradual process of decentralized individual decisions and bilateral contracts by analogy to Adam Smith's invisible hand theorem (Smith 2007[1776]). For Nozick (1974) such invisible hand justifications are particularly convincing, because they "minimize the use of notions constituting the phenomena" in question and refrain from justifying "complicated patterns by including the full-blown pattern-notions as objects of people's desires or beliefs" (p. 19). Table 2 summarizes the argument, which begins with an account of the state of nature. 
Table 2 The logical structure of a counterfactual contractarian justification for employment injury insurance. Source Adapted from Müller (2002, p. 471) and applied to the present case

\begin{tabular}{|c|c|c|}
\hline General Form & Specific Components & Application to the Present Case \\
\hline $\begin{array}{l}\text { Explanandum/Projectandum: } \\
\text { What is the object of the } \\
\text { hypothetical } \\
\text { explanation/prediction? }\end{array}$ & $\begin{array}{l}\text { Resulting Social Contract: } \\
\text { Individuals (will) agree to rule } \\
\text { r, principle p, or institution i }\end{array}$ & $\begin{array}{l}\text { Stage 5: Compulsory Injury Insurance } \\
\text { Both sides want to reduce the cost of } \\
\text { conflict by creating an insurance system }\end{array}$ \\
\hline \multirow[t]{4}{*}{$\begin{array}{l}\text { Explanans/Projectans: } \\
\text { What drives the hypothetical } \\
\text { explanation/prediction? }\end{array}$} & \multirow{3}{*}{$\begin{array}{l}\text { Deterministic Mechanism } \\
\text { I Rontract: } \\
\text { I the alternative which best } \\
\text { I satisfies their subjective } \\
\text { I motives under given objective } \\
\text { I invisible hand, their self- } \\
\text { I interested decisions gradually } \\
\text { I lead to a voluntary, though } \\
\text { Initially unintended social } \\
\text { contract }\end{array}$} & $\begin{array}{l}\text { Stage 4: Expansion } \\
\text { Due to the nature of the insurance } \\
\text { service markets tend to concentrate }\end{array}$ \\
\hline & & $\begin{array}{l}\text { Stage 3: Organization } \\
\text { Institutionalized help reinforces wor- } \\
\text { ker claims to natural/contractual rights }\end{array}$ \\
\hline & & $\begin{array}{l}\text { Stage 2: Spontaneous Association } \\
\text { Workers help each other to deal with } \\
\text { accidents and to assert their claims }\end{array}$ \\
\hline & $\begin{array}{l}\text { Hypothetical Original } \\
\text { I Position: } \\
\text { I } 1 . \text { Individual motives (desires, } \\
\text { I } 2 \text {. Defencesion, life plans...) } \\
\text { I information, endowments...) }\end{array}$ & $\begin{array}{l}\text { Stage 1: Unregulated Labor Market } \\
\text { 1. Employers/workers are respectful of } \\
\text { natural rights and willing to cooperate } \\
\text { 2. Labor contracts are incomplete, and } \\
\text { libertarian default rules are ambiguous }\end{array}$ \\
\hline
\end{tabular}

\section{State of Nature: Disputed Claims in Cases of Work Accidents}

The Nozickian argument proceeds from a Lockean state of nature (Stage 1 in Table 2) as one of the most optimistic types of anarchy conceivable (Kliemt 1980, p. 38). It is a hypothetical situation in which individuals are in a "state of perfect freedom to order their actions and dispose of their possessions and persons as they think fit, [...] without asking leave, or depending upon the will of another" (Locke 2009[1689], §4, italics in the original). Moreover, it is a "state [...] of equality, wherein all the power and jurisdiction is reciprocal, no one having more than another" (ibid). In such a situation, individuals are free to live, work or locate their business anywhere. They may engage in a joint enterprise to which some contribute capital in the form of buildings, machines and raw materials, while others supply labor for the production of marketable goods. However, as no one is subject to another, their cooperation, for example, in terms of a typical employment relationship in sweatshops, must follow from a voluntary contract (Rothbard 1998, p. 133).

As the Lockean state of nature is a "state of liberty", but "not a state of license" (Locke 2009[1689], §6, emphasis removed), individuals will stay "within the bounds of the law of nature" (ibid, §4) when exercising their freedom (of contract), which requires that "no one ought to harm another in his life, health, liberty, or possessions" (\$6). Hence, individuals will act in line with the libertarian constraints of "Libertarianism" section. In contract negotiations they will neither threaten nor deceive their counterpart, and they will conclude voluntary, Pareto-improving contracts.
However, even in this most favorable state of nature, work accidents may occur. In sweatshop production, they are all too often unavoidable, especially when dangerous machines, hazardous substances, exhausting physical work, and interpersonal coordination are involved. In the event of an injury or illness, the question will arise as to who must cover the resulting medical costs and loss of income.

By virtue of their systematic incompleteness, labor contracts will not contain detailed provisions for the settlement of such claims (Tirole 1999). Due to the long-term orientation and complexity of the underlying employment relationship and the difficulties in anticipating future developments at the time of transaction, they will inevitably be vague on the nature of tasks, working conditions, as well as liabilities and financial obligations in the event of accidents (Sturn 2009). Forward-looking employers and workers will have agreed on general rights and obligations. In a Lockean scenario, it seems reasonable to assume that they are prepared to take responsibility for things in their respective sphere of influence. Workers will feel responsible for the diligent fulfillment of their tasks and the immediate impact of their actions on co-workers, and employers will assume responsibility for machine and workplace equipment and the nature of the workflow. As Lockeans they are likely to settle on rules which assign liability for accidents based on negligence within these spheres of influence (a detailed description in Epstein 1982, p. 775).

In line with the argument in "Libertarian Responsibility and Obligations in Incomplete Labor Contracts," employers recognize their libertarian obligation to protect the health of workers and to compensate them for occupational health 
problems resulting from negligence in their area of responsibility. In the event of an accident most victims make reasonable and legitimate compensation demands and most employers will meet them. However, in a legal vacuum without clearly defined health and safety standards, it will not be clear which precautionary steps an employer should have undertaken in order to meet his obligation to protect the health of workers. Similarly, without a clear-cut legal standard on maximum working hours it will be unclear whether an injured worker was negligent or overworked. Even a detailed contractual liability structure might not help contractors to identify retrospectively the originators and causal factors of an accident or illness. ${ }^{3}$ Accordingly, despite their acceptance of responsibility for the intentional or negligent violation of rights of others, employers and workers will eventually end up disagreeing on the appropriate interpretation of libertarian obligations within incomplete labor contracts.

In a Lockean state of nature, everyone is entitled to take the (natural) law into his own hands "so far as calm reason and conscience dictate" (ibid, §8). Again, reasonable victims will seek an amicable solution with rights violators. However, not all of them will be capable of a calm and prudent reaction. Some injured workers or their dependents might make excessive demands and get carried away when enforcing them, due to miscalculation, anger or desperation (Nozick 1974, p. 11). For similar reasons, some employers might reject legitimate compensation claims.

Against this backdrop of incomplete information, vague contractual rules, diverging interpretations of libertarian obligations, misjudgments and overreactions, this kind of "private and personal enforcement of one's rights (including those rights that are violated when one is excessively punished)" can quickly give rise "to an endless series of acts of retaliation and exactions of compensation" (ibid). Individuals will experience this uncertainty as a deficiency in the otherwise quite favorable state of nature, not least because any conflict entails considerable disadvantages in terms of negotiation costs, defense efforts or emotional strain.

\section{Loose Association: Unstructured Mutual Assistance}

In a possible conflict, injured workers and their families are in a much weaker position than employers, due to the urgent need to compensate sudden income loss and accruing medical costs. In the event of repeated cases in their community,

\footnotetext{
${ }^{3}$ In hindsight, it might be difficult to distinguish a machine error from an operating error. The injured person, as the only witness of an incident, might no longer be responsive or no longer recall the precise course of events. Production managers or supervisors might not be aware that one of their instructions triggered a chain of events that led to the accident.
}

workers will eventually form loose associations for mutual assistance in order to help accident victims cope with their existential problems (Stage 2 in Table 2). Initially, they might simply offer spontaneous help to injured co-workers and their families. Out of friendship, public-spiritedness, religious duty or in exchange for a past favor (Nozick 1974, p. 12), they might collect money to help them survive the income loss after an accident, to cover medical costs or to finance efforts to claim damages from employers. As shown by Hochman and Rogers (1969), even charitable assistance can be a Pareto-improving form of redistribution. ${ }^{4}$

However, membership of an association for mutual assistance does not require altruistic motives or personal attachments. Some might join it based on a purely self-interested 'insurance motive'. Brennan (1973) shows that "quite apart from any philanthropic considerations, an individual may be prepared to contribute towards redistributive programmes [...] because in the face of certain privately uninsurable contingencies, raising the floor level of income precludes or substantially reduces the possibility of complete destitution" (p. 43). Similarly, sweatshop workers must reckon with the possibility of an accident or health problem that suddenly exposes them to a desperate situation, which they can no longer overcome by themselves due to their incapacitation. Reluctant to end up helpless and dependent on the goodwill of others, even self-interested workers might want to make provisions. They may be "prepared to pay something to insure against potential cataclysms" (ibid, p. 45). As most of them receive (near) subsistence wages (Arnold and Bowie 2003), they would not be able to insure privately against a complete loss of earning capacity. ${ }^{5}$ However, jointly they could insure affected contributors. Recognizing that they might end up unlucky, ex-ante they might be willing to contribute, even though ex-post it turns out to be a losing deal. ${ }^{6}$

\section{Organization: Structured Mutual Insurance}

Recurring health problems and the insight that everyone could suffer an accident or illness would promote a gradual institutionalization of mutual assistance. The corresponding

\footnotetext{
${ }^{4}$ If the utility of a healthy community or association member $U_{H}$ depends on the utility of an injured member $\mathrm{U}_{\mathrm{I}}$, due to an emotional bond or feeling of personal obligation captured by $\partial \mathrm{U}_{\mathrm{H}} / \partial \mathrm{U}_{\mathrm{I}}>0$, redistribution from the former to the latter will make both of them better off. The same applies to the n-player scenario (p. 443).

${ }^{5}$ In line with an argument by Braun (2012) in the context of health insurance, the insurance motive of workers might encompass their desire to maintain their earning capacity. By ensuring the rapid treatment of injuries, insurance contributes to the avoidance of long-term health problems with a negative impact on the ability to work.

${ }^{6}$ Here, it is important to note that in his model Brennan (1973) assumes "that all individuals are both risk averse and risk loving over relevant ranges, so as to permit the desire for redistribution to be con-
} 
associations would begin to charge a periodic and mandatory membership fee in order to build up the necessary funds for helping workers in need more rapidly and more reliably. ${ }^{7}$ Initially, these associations would be unstructured and operate on the principle of 'one for all and all for one' (Kliemt 1980, p. 40). Each contributing member would have the same rights and obligations, including non-financial obligations to participate in collective decisions, such as on member admissions, membership fee levels, compensation levels, or strategies for resolving disputes with employers. As the number of collective decisions and the associated efforts would increase with the number of members, associations will have an optimal size, somewhere near the point where the marginal benefit of accession equals the marginal cost (Kliemt 1980, p. 40).

Eventually, workers would figure out that their associations can become more efficient if they introduce a division of labor, and that it enables them to offer their members a more attractive cost-benefit package in comparison to that of less efficient associations. For instance, the delegation of cumbersome administrative duties to specialized functionaries in deviation from the principle of 'one for all and all for one' would make it possible for members to enjoy the collective support of the others in the event of problems, while at the same time giving them the opportunity to concentrate on their private projects.

A similar efficiency gain would come with the introduction of internal rules for disciplining possible spending sprees by functionaries, and for keeping in check the problems of adverse selection and moral hazard. Adverse selection (e.g., Akerlof 1970) describes the problem that membership in the association is particularly attractive to venturesome and confrontative individuals with an inclination to exhaust a larger share of available funds. Moral hazard (e.g., Finkelstein 2015), captures the problem that some previously cautious members might begin to take higher

\footnotetext{
Footnote 6 (continued)

sistent with an observed propensity to gamble (as well as to insure)" (p. 45; emphasis in the original)

7 They might function along the lines of medieval predecessor organizations of miner's guilds in Germany, which formed as an institution "to jointly shoulder financial uncertainty due to erratic, immediate income losses resulting from sickness or injuries" (Jopp 2013, p. 50). At the outset, these guilds provided assistance at a very basic level and by the "organizing principle" of voluntarily offered charity or philanthropy (ibid). Over time, however, more and more of them "demanded regular and obligatory contributions from their members" and "benefits were provided in the case of need, simply so long as the cash box allowed [sic.]" (ibid). Trade unions in states without welfare institutions ran similar solidarity/insurance funds (Murray 2007, ch. $6)$.
}

risks at work after joining the association, confident that the others will now help them in case of an accident. Suitable rules for the containment of these problems would ensure that collective funds are managed efficiently, and again would give structured organizations an evolutionary advantage over loose associations. From the perspective of reasonably cautious members acting on the insurance motive, they would be more attractive than unstructured associations by virtue of their ability to offer cheaper and more reliable insurance coverage. ${ }^{8}$

\section{Concentration: Gradual Market Consolidation}

Initially, multiple insurance organizations in an area will be competing for members. Market competition will be a major driver of the described process of organizational evolution. Organized providers with specialized functionaries and efficient internal rules will attract more members than loose associations, by virtue of being able to offer more attractive and cheaper protection packages. However, the market for organized employment injury insurance will be subject to strong concentration processes, due to several economic factors (Stage 4 in Table 2).

On the supply side, economies of scale (Sharkey 2009) which lower the cost of providing their service would be a key driver of market concentration. Larger organizations can spread the fixed costs of their capacities for screening applicants, administering members, evaluating insurance cases or enforcing claims over a larger number of members, compared to smaller organizations. This would enable them to offer their service at a lower per capita price and

\footnotetext{
8 Again, German miners' guilds are a suitable historical example that renders plausible the transition from an unstructured mutual assistance association to a structured mutual insurance organization. Due to adverse selection and moral hazard, over time, their organizing principle moved from needs-based charitable assistance to contribution-based benefit entitlements for members "broadly equivalent to their mandatory payments" (Jopp 2013, p. 53). Ultimately, the described structured organizations might function along the lines of U.S. American sickness insurance funds, which emerged at the beginning of the twentieth century as an institutional response to the problem of occupational sickness and injury (Murray 2007, p. 5). They also began to address the problem of adverse selection by formulating rules of admission, which prevented an overuse of the organization's financial means, by excluding excessive risk-takers and conflictseekers. In addition, they developed a differentiated service portfolio with variable insurance premiums and insurance benefits, tailored to the specific needs and risk profiles of workers. They also tackled the problem of moral hazard by checking the circumstances of an accident or illness and refusing benefits to those who had caused it intentionally or negligently.
} 
would give them a competitive advantage. ${ }^{9}$ Moreover, large organizations are able to provide more reliable insurance to their members because, by the law of large numbers, the actuarial risk of an insurance provider decreases with a rising number of members. This means that large insurance providers are less vulnerable to insolvency, because they are better at predicting actual insurance claims (Jopp 2013, ch. 4). Again, this gives them a systematic advantage over smaller competitors.

On the demand side, network effects (Liebowitz and Margolis 1994) are a major driver of market concentration. They capture the phenomenon that the utility of membership for a (potential) client, in terms of the organization's ability to solve conflicts in his interest, depends on the number of other clients. There are two reasons for this. First, the more workers in a given workforce are in the same organization, the more likely it is that they can settle a dispute between them. This occurs, for example on the issue of whether one of them caused harm to the other, based on the lower-cost internal rules and adjudication mechanisms of their joint insurer. Second, the more members an organization has, the more assertive it will be in conflicts with employers and co-workers who are not members. Larger organizations will simply be able to afford top class negotiators in cases of peaceful disputes, but will also have better chances of success in less peaceful conflicts by virtue of their ability to mobilize a larger number of members. Such demand-side network effects can induce both positive and negative feedback loops (Katz and Shapiro 1985), making large insurers even larger and sending small ones into a "declining spiral" (Nozick 1974, p. 17). In sum, these economic factors lead to a situation in which most workers in a company or an industry will be members in a single or in a few large insurance organizations. ${ }^{10}$

\section{Monopolization: The Compensation Bargain}

Even a monopoly insurance provider falls short of a compulsory employment injury insurance system that is backed up by a governmental monopoly of force. Despite its market-dominating position, it does not force all labor market

\footnotetext{
${ }^{9}$ If the lowest point of a U-shaped average cost curve in a market is to the right of the demand curve, there will even be a natural monopoly, i.e., a monopolist will be able to accommodate the demand of the market at a lower per capita price than any number of competing providers. On the economics of natural monopoly Sharkey (2009).

10 The evolutionary history of actual insurance systems makes the described dynamic plausible. Jopp (2013) explains the historical concentration process of German miner's associations in terms of economies of scale regarding administrative costs and actuarial risk, and supports his theoretical explanation with an empirical analysis of historical records. Murray (2007) describes a similar concentration dynamic of private US insurance providers.
}

participants to purchase its services, as a governmental system would. Nor does it prohibit non-members from making use of their natural right to determine a rights violation and to claim compensation independently, in line with their own procedure. A governmental system would have to be mandatory for all market participants and would have to impose on them, its rules for settling disputes (Nozick 1974, pp. 22-23).

The transition to a governmental system (Stage 5 in Table 2) would result from (the prospect of) confrontations between large insurers and employers in the wake of occupational accidents or health problems, with unclear liabilities and contested safety and compensation claims. As legitimate defenders of their clients' libertarian second-order rights (Child 1994) insurers attempt to collect appropriate compensation for accident victims and would pressure employers to reduce serious risks to the health of workers in the future. In view of gaps in incomplete labor contracts, they would apply their own procedures for determining negligence and appropriate compensation levels, based on their members' joint interpretation of libertarian principles. This also applies to employers who would prefer to apply their own interpretation and procedures. ${ }^{11}$

In cases of disagreement they will end up in a conflict that can take many forms, ranging from negotiations to industrial disputes with work stoppages, strikes, lockouts, wage cuts and layoffs. Both sides would be aware of their power to inflict considerable harm on each other and would realize that the other side has a realistic chance of gaining the upper hand, insured workers due to superior numbers and employers due to superior financial means. This prospect of costly and potentially ruinous confrontations in the board room, on the factory floor or in the streets, provides them with a powerful reason to seek a mutually acceptable agreement. Especially libertarians would prefer to overcome disagreements through negotiations (Nozick 1974, p. 16) or the delegation of cases to independent arbitrators (Rothbard 1998, p. 234). Considering the behavioral assumptions in the state of nature, conflicts will hardly turn as violent as similar disputes in the history of labor relations (Marens 2012, p. 65).

\footnotetext{
${ }^{11}$ In the course of their organizational evolution, insurers will have developed mechanisms for approaching disputes in a way that their members perceive as fair and reliable. They will have established refined procedures for identifying a violation of natural rights, determining guilt, setting appropriate levels of compensation and punishment, and enforcing them proportionately. Similarly, employers will be convinced that they, as organizers of the production process, have the best overview of the case in question and that their judgment is more reliable. Especially in matters where the conflict parties feel in the right, they will try to stand their ground in full accordance with the law of nature, which gives them the same natural right to have a case settled in line with their preferred procedure (Kliemt 1980, p. 73).
} 
As shown by Brennan (1973), even those in a more favorable position can have a self-protection motive to contribute financially to the insurance of those in a less favorable position. In the present case, this means that the party that genuinely believes itself to be in the right has a reason to pay at least some of the costs of a potentially illegitimate claim in order to avoid an even costlier conflict. Accordingly, jointly financing an insurance system irrespective of liabilities can be another Pareto-desirable form of redistribution between employers and workers (ibid).

This logic seems to underlie the compensation bargain at heart of most existing governmental employment injury insurance systems. It captures an agreement that employers contribute to the coverage of insurance cases, regardless of their own negligence, in exchange for a renunciation by workers of any further attempts to gain redress. The compromise consists of workers accepting levels of compensation below what would be due to them according to their own interpretation of libertarian precepts and employers assuming responsibility for those cases for which they (might) have no blame (Larson 1952). In his historical analysis of the emergence of workers' compensation law, Epstein (1982) summarizes the underlying rationale:

"The broad coverage formula eliminated the need to determine negligence on both sides and assumption of risk-all inquiries with a high degree of uncertainty. In exchange for the broad coverage formula, the workman received a level of compensation that, by design, left him worse off than if the injury itself had never taken place. The low levels of the benefits doubtless proved nettlesome to workers after injuries. But to concentrate on that point is to miss the central role. First, low damages help keep down the overall costs of the plan, which will induce employers to continue to hire labor. Second, low benefits help prevent fraud against the plan, as there is less to gain by pretending that an injury, or its consequences, is work-related. Third, the low awards create additional incentives upon the worker for self-protection and therefore act as an implicit substitute for assumption of risk and contributory negligence.” (pp. 800-801).

However, the described compensation bargain only works under three conditions that transform the monopoly insurer into a governmental system. The first condition requires the integration of all independent workers into the bargain (Kliemt 1980, p. 52). Otherwise, employers would have made concessions to members of insurance organizations (and vice versa), while still facing the possibility of costly disputes with independents. However, once employers have joined the insurance organization in search of a Paretoimprovement over costly disputes, they can simply require membership as an obligatory term of labor contracts. By libertarian standards, it is their legitimate right to terminate the contracts of workers who refuse insurance, and to hire only those workers who accept it as part of the deal. This will quickly promote universal coverage. ${ }^{12}$

The second condition for a functioning compensation bargain requires the formulation and enforcement of industrywide health and safety standards. These standards are necessary for detecting and avoiding moral hazard on the part of employers who have an incentive to take higher risks at the expense of other employers once they are covered (Dionne and St-Michel 1991; Bolduc et al. 2002). ${ }^{13}$ They provide an objective point of reference for determining whether employers have fulfilled their obligation to protect the health and safety of their workers, thus enabling the insurance provider to reclaim illegitimate compensation payments to workers from negligent employers. ${ }^{14}$ By discouraging employer negligence or fraud, labor standards also play a key role in keeping down the overall costs of the insurance system.

A third condition for a functioning compensation bargain requires the transfer of control of the insurance system to an impartial third party. Otherwise, workers and employers would run the risk of merely resuming their initial conflict within its decision-making bodies. Workers might try and define labor standards in a manner that offers them the highest degree of protection affordable, whereas employers would prefer to keep labor standards low in order to maximize their profits. In order to prevent a blockage of their joint system, both sides would have an interest in delegating responsibility for it to a trustworthy third party with the ability to resolve conflicts as impartially as possible. Especially employers would demand this, considering that the principle of 'one person, one vote' would provide them with little influence on collective decisions. The success of this third party depends on its institutional independence and uncompromising commitment to the organization's interpretation of libertarian principles. Like a trustee, once (re-)elected

\footnotetext{
12 As independents are still free to decline the offer and leave the company, it does not violate their natural rights. To an even greater extent this applies to independents who remain unemployed due to the negative employment effects of higher wage costs in the labor market. Even though they are worse off than before, they cannot complain about a violation of their libertarian rights either, as no employer has a positive duty to offer them a job.

13 Competition with other locations (Porter 1998) that still lack a comparable system, e.g., because the local government coercively prohibits labor unions, will only reinforce this motive.

${ }^{14}$ For example, maximum working hours reduce the risk of fatiguerelated accidents. They provide orientation to the insurer for assessing whether an employer negligently accepted fatigue on the part of workers prior to an accident. The prospect of having to pay for the arising costs provides an incentive for employers to observe maximum working hours.
} 
it would have to be insulated from any direct influence by workers and employers when exercising its role. ${ }^{15}$

Under the control of this impartial third party, the employment injury insurance system would exhibit all relevant characteristics of a Nozickian minimal state. No participant in the labor market could escape it. Membership would entail mandatory financial contributions. The system would impose its procedures for assessing accidents including industry-wide labor standards. It would require renunciation of the natural right to claim compensation independently. And it would be run by individuals with an obligation to act strictly in the interest of all members. In a population of rights-respecting libertarians no one would have to fear an abuse of power by those individuals, as they would also be rights-respecting libertarians in accordance with the initial assumptions about the state of nature (Kliemt 1980, pp. 44-45).

All this shows that a governmental insurance system with those properties, that imposes labor standards, is legitimate because it would (hypothetically) emerge from a maximally favorable state of nature (Kliemt 1980, p. 37) and in a gradual process that respects the natural rights of affected individuals (Bader 2017) and "that in no way had the overall pattern or design 'in mind"' (Nozick 1974, p. 18). This serves as an ideal for actual governmental insurance systems which might tend to gradually extend their reach beyond the described functions.

\section{Conclusion}

The present article addresses the problem of occupational sickness and injury in sweatshops. More specifically, it provides a libertarian analysis of the normative question of whether sweatshop owners have obligations towards their workers, and to what extent they should look after them and their dependents in the wake of work-related health problems. The work reveals that libertarian premises imply an employer obligation to protect the life and health of workers and to compensate them in the event of accident- and work-related incapacitation. Based on Nozick's contractarian method, it then argues that those obligations should be implemented in a governmental employment injury insurance system that coercively enforces health and safety standards as an integral part of its role. Those results challenge the choice argument against sweatshop regulation, which categorically rejects any employer obligations towards injured workers and any regulative measures to protect their health,

\footnotetext{
15 For an impression as to how this can be achieved in reality, see Sokoll (1997).
}

based on the argument that they have tacitly accepted occupational risks when taking up their job.

Acknowledgements Open Access funding provided by Projekt DEAL.

Funding I (Damian Bäumlisberger) declare that I did not receive any specific funding for this study.

\section{Compliance with Ethical Standards}

Conflict of interest All authors declare that they have no conflict of interest.

Open Access This article is licensed under a Creative Commons Attribution 4.0 International License, which permits use, sharing, adaptation, distribution and reproduction in any medium or format, as long as you give appropriate credit to the original author(s) and the source, provide a link to the Creative Commons licence, and indicate if changes were made. The images or other third party material in this article are included in the article's Creative Commons licence, unless indicated otherwise in a credit line to the material. If material is not included in the article's Creative Commons licence and your intended use is not permitted by statutory regulation or exceeds the permitted use, you will need to obtain permission directly from the copyright holder. To view a copy of this licence, visit http://creativecommons.org/licenses/by/4.0/.

\section{References}

Akerlof, G. A. (1970). The market for "Lemons": Quality uncertainty and the market mechanism. The Quarterly Journal of Economics, 84(3), 488-500.

Alamgir, F., \& Alakavuklar, O. N. (2018). Compliance codes and women workers' (mis)representation and (non)recognition in the apparel industry of Bangladesh. Journal of Business Ethics. https://doi.org/10.1007/s10551-018-4080-2.

Alliance for Bangladesh Worker Safety ABWZ. (2018). Protecting the Lives and Livelihoods of Bangladesh's Garment Workers. First Annual Report of the Alliance for Bangladesh Worker Safety July 2014. Retrieved from Feb 12, 2019 https://www.bangladesh workersafety.org/files/2014-annual-report/Alliance\%20Ann ual\%20Report, \%202014.pdf.

Arneson, R. J. (1982). The principle of fairness and free-rider problems. Ethics, 92(4), 616-633.

Arnold, D. G., \& Bowie, N. E. (2003). Sweatshops and respect for persons. Business Ethics Quarterly, 13(2), 608-624.

Arnold, D. G., \& Bowie, N. E. (2007). Respect for workers in global supply chains: Advancing the debate over sweatshops. Business Ethics Quarterly, 17(1), 135-145.

Ayres, I., \& Gertner, R. (1989). Filling gaps in incomplete contracts: An economic theory of default rules. Yale Law Journal, 99(1), 87-130.

Bader, R. (2017). Counterfactual justifications of the state. In D. Sobel, P. Vallentyne, \& S. Wall (Eds.), Oxford studies in political philosophy (Vol. 3, pp. 101-131). Oxford: Oxford University Press.

Barnett, R. E. (1992a). Rational bargaining theory and contract: Default rules, hypothetical consent, the duty to disclose, and fraud. Harvard Journal of Law and Public Policy, 15(3), 783-803.

Barnett, R. E. (1992). The sound of silence: Default rules and contractual consent. Virginia Law Review, 78, 821-911.

Barrientos, S., Gereffi, G., \& Rossi, A. (2011). Economic and social upgrading in global production networks: A new paragidm 
for a changing world. International Labour Review, 150(3-4), 319-340.

Becker, G. S. (1968). Crime and punishment: An economic approach. Journal of Political Economy, 76(2), 169-217.

Block, W. (2008). Labor economics from a free market perspective: Employing the unemployable. Singapore: World Scientific.

BMZ Bundesministerium für Wirtschaftliche Zusammenarbeit und Entwicklungshilfe. (2016). Die Antworten des BMZ auf Rana Plaza (The BMZ's Response to Rana Plaza). Factsheet by Germany's Federal Ministry for Economic Cooperation and Development from April 2016. Retrieved from Feb 12, 2019 https:// www.textilbuendnis.com/wp-content/uploads/2017/06/Facts heet_Rana_Plaza_April_2016_115_final.pdf.

Boatright, J. (2006). What's wrong — and What's right—with stakeholder management. Journal of Private Enterprise, XXI(2), 106-131.

Bolduc, D., Fortin, B., Labrecque, F., \& Lanoie, P. (2002). Workers' compensation, moral hazard and the composition of workplace injuries. The Journal of Human Resources, 37(3), 623-652.

Bou-Habib, P. (2006). Compulsory insurance without paternalism. Utilitas, 18(3), 243-263.

Braun, S. S. (2012). Mandatory health insurance, liberalism, and freedom. Public Affairs Quarterly, 26(3), 179-197.

Brennan, G. (1973). Pareto-desirable redistribution: The non-altruistic dimension. Public Choice, 14(1), 43-67.

Brink, A. (2010). Enlightened corporate governance: Specific investments by employees as legitimation for residual claims. Journal of Business Ethics, 93(4), 641-651.

Buchanan, J. (1975). The limits of liberty: Between anarchy and leviathan. Chicago: The University of Chicago Press.

Buchanan, J. (1990). The domain of constitutional economics. Constitutional Political Economy, 1(1), 1-18.

Carson, T. L. (2013). Free exchange for mutual benefit: Sweatshops and Maitland's "Classical Liberal Standard". Journal of Business Ethics, 112, 127-135.

Child, J. W. (1994). Can libertarianism sustain a fraud standard? Ethics, 10(4), 722-738.

Christmas, B. (2018). Rescuing the libertarian non-agression principle. Moral Philosophy and Politics, 5(2), 305-325.

Coakley, M., \& Kates, M. (2013). The ethical and economic case for sweatshop regulation. Journal of Business Ethics, 117(3), 553-558.

Coase, R. H. (1937). The nature of the firm. Economica, 4(16), 386-405.

Dionne, G., \& St-Michel, P. (1991). Workers' compensation and moral hazard. Review of Economics and Statistics, 73(2), 236-244.

Ehrenberg, R. G., \& Smith, R. S. (2012). Modern labor economics: Theory and public policy (11th ed.). Boston: Prentice Hall.

Epstein, R. A. (1982). The historical origins and economic structure of workers' compensation law. Georgia Law Review, 16(4), 775-819.

Finkelstein, A. (2015). Moral hazard in health insurance. Kenneth J. Arrow Lecture. New York: Columbia University Press.

Flanigan, J. (2017). Rethinking freedom of contract. Philosophical Studies, 174(2), 443-463.

Flanigan, J. (2018). Sweatshop regulation and workers' choices. Journal of Business Ethics, 153(1), 79-94.

Fontana, E., \& Egels-Zandén, N. (2018). Non sibi, sed omnibus: Influence of supplier collective behavior on corporate social responsibility in the Bangladeshi apparel supply chain. Journal of Business Ethics, 159, 1047-1064.

Fritsch, M. (2011). Marktversagen und Wirtschaftspolitik: Mikroökonomische Grundlagen staatlichen Handelns, 8th (revised ed.). Munchen: Verlag Franz Vahlen GmbH.

Gereffi, G., \& Lee, J. (2016). Economic and social upgrading in global value chains and industrial clusters: Why governance matters. Journal of Business Ethics, 133, 25-38.
Greene, Z., Henry, S., Nathanson, C., \& Block, W. (2007). Negative impacts of minimum wage and anti-sweatshop legislation. Humanomics, 23(2), 83-92.

Handfield, T. (2003). Nozick, prohibition, and no-fault motor insurance. Journal of Applied Philosophy, 20(2), 201-208.

Hart, O., \& Moore, J. (1985). Incomplete contracts and renegotiation. Working Paper of the Department of Economics. Massachusetts Institute of Technology.

Hämäläinen, P., Takala, J., \& Kiat, T. B. (2017). Global estimates of occupational accidents and work-related illnesses 2017. Study by the World Safety and Health Institute Singapore and the Ministry of Social Affairs and Health Finland in cooperation with the International Labor Organization and based on classifications by the World Health Organization. Retrieved August 8, 2019 https://www.icohweb.org/site/images/news/pdf/Repor $\mathrm{t} \% 20$ Global\%20Estimates\%20of\%20Occupational\%20Accident s\%20and\%20Work-related\%20Illnesses\%202017\%20rev1.pdf

Hämäläinen, P., Saarela, K. L., \& Takala, J. (2009). Global trend according to estimated number of occupational accidents and fatal work-related diseases at region and country level. Journal of Safety Research, 40, 125-139.

Hochman, H. M., \& Rodgers, J. D. (1969). Pareto optimal redistribution. American Economic Review, 59(4), 542-557.

Hobbes, T. (1968[1651]). Leviathan: Or, the matter, forme and power of a commonwealth. Harmondsworth: Penguin.

ILO International Labor Organization. (2018). Bangladesh move towards employment injury insurance: The legacy of rana plaza. Publication on the ILO website on 13 June 2018. Retrieved from Feb 2, 2019 https://www.ilo.org/wcmsp5/group s/public/---ed_emp/documents/publication/wcms_632364.pdf.

ILO International Labor Organization. (2017). ILO strategy for employment injury insurance and workers' compensation. Publication date: 4 Sep 2017. Retrieved from Feb 12, 2019 https ://www.ilo.org/wcmsp5/groups/public/---ed_emp/---emp_ent/ documents/publication/wcms_573083.pdf.

ILO International Labor Organization. (2012). ILO Global Estimate of Forced Labor: Results and Methodology. International Labor Office-Special Action Programme to Combat Forced Labor (SAP-FL). Geneva. Retrieved from Mar 12, 2019 https ://www.ilo.org/wcmsp5/groups/public/---ed_norm/---declaratio n/documents/publication/wcms_182004.pdf.

Jopp, T. A. (2013). Insurance, fund size, and concentration: Prussian miners' knappschaften in the nineteenth- and early twentieth centuries and their quest for optimal scale. Beihefte des Jahrbuchs für Wirtschaftsgeschichte, 16. Berlin, Akademie Verlag.

Jopp, T. A. (2010). The welfare state evolves: German Knappschaften, 1854-1923. Business and Economic History On-Line, 8, $1-20$.

Kates, M. (2015). The ethics of sweatshops and the limits of choice. Business Ethics Quarterly, 25(2), 191-212.

Katz, M. L., \& Shapiro, C. (1985). Network externalities, competition, and compatibility. The American Economic Review, 75(3), 424-440.

Kliemt, H. (1980). Zustimmungstheorien der Staatsrechtfertigung. München: Verlag Karl Alber.

Larson, A. (1952). Nature and origins of workmen's compensation. Cornell Law Review, 37(2), 205-234.

Locke, J. (2009[1689]). Two treatises of government. In P. Laslett (Ed.), Cambridge texts in the history of political thought. Cambridge: Cambridge University Press.

Liebowitz, S. J., \& Margolis, S. E. (1994). Network externality: An uncommon tragedy. Journal of Economic Perspectives, 8(2), $133-150$.

Lin-Hi, N., \& Blumberg, I. (2017). The power(lessness) of industry self-regulation to promote responsible labor standards: Insights 
from the Chinese toy industry. Journal of Business Ethics, 143(4), 789-805.

Mack, E. (2018). Robert Nozick's political philosophy. In Zalta, E. N. (ed.), The Stanford encyclopedia of philosophy (Summer 2018 Edition). https://plato.stanford.edu/archives/sum2018/entries/ nozick-political/.

Maitland, I. (1989). Rights in the workplace: A Nozickian argument. Journal of Business Ethics, 8, 951-954.

Maitland, I. (1997). The great non-debate over international sweatshops. British Academy of Management Annual Conference Proceedings, pp. 240-265.

Malik, N., Maan, A. A., Pasha, T. S., Akthar, S., \& Ali, T. (2010). Role of hazard control measures in occupational health and safety in the textile industry of Pakistan. Pakistan Journal of Agricultural Sciences, 47(1), 72-76.

Marens, R. (2012). Generous in victory? American managerial autonomy, labour relations and the invention of corporate social responsibility. Socio-Economic Review, 10(1), 59-84.

McAdams, R. H. (2000). A focal point theory of expressive law. Virginia Law Review, 86, 1649-1729.

McAdams, R. H. (2015). The expressive powers of law: Theories and limits. Reprint 2017. Harvard University Press.

Müller, C., \& Tietzel, M. (2001). Merit goods from a constitutional perspective. In: Brennan, G., Kliemt, H., Tollison, R. D. (eds.) Method and morals in constitutional economics. Studies in Economic Ethics and Philosophy. Berlin/Heidelberg: Springer.

Müller, C. (2002). The methodology of contractarianism in economics. Public Choice, 113, 465-483.

Miklós, A. (2017). Exploiting injustice in mutually beneficial market exchange: The case of sweatshop labor. Journal of Business Ethics, 156(1), 59-69.

Murray, J. E. (2007). Origins of American Health Insurance: A history of industrial sickness funds. London: Yale University Press.

Narveson, J. (2004). Libertarianismus: Eine philosophische Einführung. Übersetzung Peter Knopf. Aufklärung und Kritik, pp. 5-37.

Nozick, R. (1974). Anarchy, state, and Utopia. Reprinted edition from 1999. Oxford: Blackwell Publishing.

PST Partnership for Sustainable Textiles (Textilbündnis). (2019). Who We Are. Retrieved from Feb 12, 2019 https://www.textilbuen dnis.com/en/who-we-are/the-partnership/.

Porter, M. E. (1998). Clusters and the new economics of competition. Harvard Business Review, 76(6), 77-90.

Powell, B., \& Zwolinski, M. (2012). The ethical and economic case against sweatshop labour: A critical assessment. Journal of Business Ethics, 107(4), 449-472.

Powell, B. (2018). Sweatshop regulation: Tradeoffs and welfare judgments. Journal of Business Ethics, 151(1), 29-36.

Preiss, J. (2014). Global labor justice and the limits of economic analysis. Business Ethics Quarterly, 24(1), 55-83.

Rothbard, M. N. (1977). Robert Nozick and the Immaculate conception of the state. Journal of Libertarian Studies, 1(1), 45-57.

Rothbard, M. N. (1998). The ethics of liberty. New York and London: New York University Press.

Schelling, T. (1980). The strategy of conflict. Cambridge, MA: Harvard University Press.

Schnellenbach, J. (2011). Wohlwollendes Anschubsen: Was ist mit liberalem Paternalismus zu erreichen und was sind seine Nebenwirkungen? Perspektiven der Wirtschaftspolitik, 12, 445-459.

Sharkey, W. W. (2009). The theory of natural monopoly. Cambridge: Cambridge University Press.

Shin, I., Oh, J.-B., \& Yi, H. K. (2011). Workers' compensation insurance and occupational injuries. Safety and Health at Work, 2(2), $148-157$.

Smith, A. (2007[1776]). An inquiry into the nature and causes of the wealth of nations. Meta Libri.
Sokoll, G. (1997). Private versus public systems for industrial accidents and invalidity insurance. The Geneva Papers on Risk and Insurance, 84(22), 336-347.

Sollars, G. G., \& Englander, F. (2007). Sweatshops: Kant and Consequences. Business Ethics Quarterly, 17(1), 115-133.

Sollars, G. G., \& Englander, F. (2018). Sweatshops: Economic analysis and exploitation as unfairness. Journal of Business Ethics, 149(1), 15-29.

Sturn, R. (2009). Volenti non fit inuria? Contract freedom and labor market institutions. Analyse und Kritik, 01(2009), 81-99.

Thaler, R. H., \& Sunstein, C. R. (2009). Nudge: Improving decisions about health, wealth and happiness. London: Penguin.

The Guardian (2018). Rana plaza, five years on: Safety of workers hangs in balance in Bangladesh. Newspaper article from 24 April 2018. Retrieved Feb 12, 2019 https://www.theguardia n.com/global-development/2018/apr/24/bangladeshi-police-targe t-garment-workers-union-rana-plaza-five-years-on.

The New York Times (NYT). (2018). Why won't we learn from the survivors of the rana plaza disaster? Newspaper article from 24 April 2018. Retrieved Feb 12, 2019 https://www.nytim es.com/2018/04/24/style/survivors-of-rana-plaza-disaster.html.

Tirole, J. (1999). Incomplete contracts: Where do we stand? Econometrica, 67(4), 741-781.

Van der Vossen, B., \& Vallentyne, P. (2018). In: Zalta, E. N. (Ed.), Libertarianism. The Stanford Encyclopedia of Philosophy (Fall 2018 Edition). https://plato.stanford.edu/archives/fall2018/entries/liber tarianism/.

Van Oosterhout, H., Heugens, P. P. M. A. R., \& Kaptein, M. (2006). The internal morality of contracting: Advancing the contractualist endeavor in business ethics. Academy of Management Review, 31(3), 521-539.

Vallentyne, P. (2007). Libertarianism and the state. Social Philosophy and Policy, 24(1), 187-205.

Velázques, L., Bello, D., Munguia, N., Zavala, A., Marin, A., \& MoureEraso, R. (2008). A survey of environmental and occupational work practices in the automotive refinishing industry of a developing country: Sonora, Mexico. International Journal of Occupational and Environmental Health, 14(2), 104-111.

Wang, X., Wu, S., Song, Q., Lap-Ah, T., Yu Ignatius, T. S., Wong, T.-W., et al. (2011). Occupational health and safety challenges in China: Focusing on township-village enterprises. Archives of Environmental \& Occupational Health, 66(1), 3-11.

Williamson, O. E. (2002). The theory of the firm as governance structure: From choice to contract. Journal of Economic Perspectives, 16(3), 171-195.

Wu, Y., Schwebel, D. C., \& Guoqing, H. (2018). Disparities in unintentional occupational injury mortality between high-income countries and low- and middle-income countries: 1990-2016. Environmental Research and Public Health, 15(10), 2296-2307.

Zeng, D. Z. (Ed.). (2010). Building engines for growth and competitiveness in China: Experience with special economic zones and industrial clusters. Directions in development: Countries and regions. Washington: The World Bank.

Zeng, D. Z. (2012). China's special economic zones and industrial clusters: Success and challenges. Lincoln Institute of Land Policy Working Paper.

Zwolinski, M. (2007). Sweatshops, choice, and exploitation. Business Ethics Quarterly, 17(4), 689-727.

Zwolinski, M. (2008). Libertarianism. The Internet Encyclopedia of Philosophy. Retrieved from March 18, 2019 https://ssrn.com/ abstract $=1069042$.

Zwolinski, M. (2016). The libertarian nonaggression principle. Social Philosophy \& Policy, 32(2), 62-90.

Publisher's Note Springer Nature remains neutral with regard to jurisdictional claims in published maps and institutional affiliations. 